\title{
The Impact of Regional and Dialectal Lexion in Literary Norm
}

\section{Gladiola Durmishi (Elezi) (Ph.D)}

\author{
Departament of Albanian language and literature, University of Vlora "Ismail Qemali", Albania \\ Email: gladiola.elezi@yahoo.it
}

\section{Doi:10.5901/ajis.2014.v3n3p410}

\begin{abstract}
Through this modest study we intend to present the large impact of regional and dialectal words in literary rate. This study aims to find the provincial dialect words and record their significance in enriching the vocabulary of the Albanian language; we study these words to see if they have or not been part of the literary rate, or if they continue or not to be used in today's spoken language. In the end, we aim to make a minidictionary, including this lexicon. In this dictionary will be included words accepted in the standard version, as well as those words that are left out. In the course of regional dialectal words included in the study, the most difficult problem has been the choice of words. Somentimes they are phonetic or grammatical dialectal variants and it looks like a new lexeme with a new meaning. Another problem would be determing whether they are part of the literary rate or not. This problem was raised in two main directions: a) in horizontal, synchronuous cutting, and b) in diachronic, vertical cutting. In synchronous cutting we study these key issues: 1) the fundamental principle of selection and provincial words that have become part of the literary rate. Here will be seen neologisms created by authors and Italian borrowings. It is about the period when a written dictionary in the Albanian language was not created and moreover standard language was not existing yet. 2) words which come from the popular spoken language and are not included in the "Dictionary of the Albanian Language". In diachronic cutting the main issue is: the lexicon included in the dictionary, if there is a change in the criteria for assessment of words or if meaning has changed, compared to FGJSH (Albanian Language Dictionary) or to previous dictionaries FGJSSH (Albanian Language Dictionary of Today) 1980 and FSS 2002. We have used a variety of methods in this study:the method of the analysis of theoretical sources: mainly used for setting the theme, collecting theoretical material, bibliography setting where a variety of books were used by different authors such as J. Thomaj "Lexicology of Albanian Language", Elsie R. History of Albanian literature etc. survey: the collection of dialect words through a questionnaire, which are the words that are not accepted in standard and still continue to be used in the language. the statistical methods for statistical tabulation of the words in the study with the aid of a computer program EXCEL 2007.For the outcomes we have used a broad range of literature that includes monographic studies as well as philological studies by different authors such as: Elsie R., E. Çabej, J.Thomai, Haxhillazi P., J.. Lloshi, B. Demas, R. Memushaj, K. Kapinovo etc. The collection of words is made in the works of N. Mjeda, Gj. Fishta, E. Koliqi, Migjeni.
\end{abstract}

\section{The Development of Standard Albanian Language}

Language is the main distinguishing element of a nation. With the creation of the national state, there is a need for a language to facilitate communication between separable parts of the country. This language should serve as a language of science, literature and higher education, but also as a sign of national identity of the people that speak that language. These needs can be met only by using the standard language. "Language can be defined as the standard variant of a codified language that serves the needs of multiple and complex communications of a linguistic community, which has created its own national state". Formation of unified national literary language (standard language) as variant processed with the language of the Albanian people has been a long process which was drafted in the centuries XVI-XVIII, but processing it entered a new period in the nineteenth century during the National Renaissance.

Naum Veqilharxhi in 1824 began work to create the alphabet and in 1844 and 1845 was published "Evetar" .Vaqilharxhi was the first to express the goals of the Albanian National Renaissance through his treaty in the introduction of "Evetar" and in many other writings.

In the Renaissance program were of great importance teaching and extension of native language, its enrichment efforts and clearing it from foreign and unnecessary word. During this period there were many literary, cultural and linguistic activities.

In 1879 it was created "Association of typing Albanian letters", which gave a new impetus to this activity. Grammars were developed first with normative goals and became the first step to design a herald of the Albanian language dictionary, which is the "Dictionary of the Albanian Language" of Constantine Christopher published after the author's death, 1904.

During the Renaissance, it was possible to draw the two literary variants of the Albanian nation, literary northern 
and southern variants. There were also efforts to adapt these variants and unify the literary language. The first task to be done, was the unification of the alphabet. Until then, the Albanian was written in some alphabets: Latin alphabet, Greek alphabet, Turkish- Arabic alphabet and special alphabets. This problem was solved in Monastery Congress held on 14 to 22 November 1908, in the city of Bitola, a city belonging to Macedonia today. In this Congress, after much discussion, it was decided to employ a new alphabet, supported entirely in Latin, filled with nine diagrams (dh, gj, II, nj, rr, sh, th, xh, zh), and two letters with diacritical marks (ç, ë), the alphabet of the Albanian language used today.

Congress accepted even the use of the Istanbul alphabet, which was widely spread, but later was used only the alphabet which was introduced in Congress, today's alphabet. Another step for the unification of Albanian literary language was made by "Albanian Literary Commission", held in Shkodra in 1916. The Commission underlined the fundamental duty of the Albanian literary language delivery and development of Albanian literature. This committee of writers and linguists was created to assist in the formation of a common literary language through literary approximation of both variants in use. It was praised literary medium variant as a bridge between Tosk and Gheg and some rules for its spelling were defined, which led to the unification of written Albanian. The decisions of Literary Albanian Commission for literary language and for its spelling were later adopted by the Congress of Lushnja Education (1920) and continued to apply until World War II.

After World War II work on the unification of the national literary language (standard language) and its spelling began to be organized by the Institute of Science. There were created special committees to draft projects on spelling.

Thus, some projects were developed in 1948, 1951, 1953 and 1956. Two scientific conference were organized in 1952 to discuss the problem of literary language. In 1967 it was published by the Institute of History and Linguistics," the new project on Albanian spelling rules. "This project was implemented in all spaces that belong to Albania Republic; in Kosovo and Montenegro. Meanwhile, efforts to unify the literary language and its spelling, were made in Kosovo too.

In 1968 the Language Consulate of Pristina convened. It was guided by the principle of "one nation-a literary language". It was decided that the orthography project of 1968 is to be officialy accepted in the Republic of Albania. It would be implemented in Kosovo too. Decisions of the Consulate have been extremely important for the unification of Albanian national literary language.

It was presented for discussion at the Congress of the spelling of the Albanian language the "Project of Albanian spelling rules" of 1967. It was convened in Tirana in 1972 and it entered the history of the Albanian language and Albanian culture as the Congress for the unification of the national literary language.

Albanian language spelling Congress which was attended by delegates from all districts of Albania, Kosovo, Macedonia and Montenegro and Arbëresh of Italy, after analyzing all the work done so far for the unification of literary language, adopted a resolution in which, among others, claimed that "the Albanian people have already unified literary language".

Unified national literary language (standard language) was mainly based in southern literary version, especially in the phonetic system but there are also integrated elements of literary variant of the north.

After Spelling Congress, were published a series of important works codifying the standard norms of language, such as "Spelling of Albanian Language" (1973), "Dictionary of literary language of today (1980), Dictionary of Albanian today (1984), the Albanian language spelling dictionary (1976), the grammar of today's Albanian language of Morphology (1995), Syntax II (1997).

\subsection{Lexicon of the Albanian language, its historical evolution}

Albanian is one of the oldest languages in Balkan. It is already proven definitely that it constitutes of a separate branch of Indo-European language family, but as Eqerem Çabej has stated, Albanian language has not derived from the IndoEuropean language family. Despite the proximity to the grammatical system in the lexicon, we can say it has developed in parallel with the languages of this family.

When we talk about the Albanian language, we point not necessarily historic, terrestrial, social boundaries etc. The Albanian language is very rich in means of expression tools, full system of phonetic, grammatical, lexical, word-and stylistic devices which have served for linguistic agreement between Albanians wherever they have been, since the period of the formation of the Albanian population that serves in our days. Part of this great unit is today's Albanian language which starts from the period of renaissance up to today.

Studies on some characteristics of the Albanian vocabulary development over the centuries, according to testimony that give us written works, have been made by Eqerem Çabej, Selman Riza, Idriz Ajeti etc. and foreign albanalogs Gustav Mayer, Norbert Jokl etc. The history of the written language, which is easy to follow step by step, in a direction serves to explain the current state of the Albanian language. This is a brief description of some features of the 
Albanian language in different periods of the vocabulary development:

In the sixteenth and seventeenth centuries, as appears in the works of ancient authors (of John Buzuku, Pjetër Budi, Frank Bardhi, Pjetër Bogdani, Lekë Matrënga, John Kazazi etc.), the Albanian language appears as generally processed and rich in vocabulary. We find words and expressions belonging to Old Albanian. These authors took care to preserve our vocabulary, to bring to light "old and forgotten words" as Pjetër Bogdani says, our language should be kept clean. In the "Latin - English Dictionary" of Franc Bardhi (1635) we find some words that may be see like new formations; kërkues, këshilltar, kopështar, letërare, luftëtare, ndërrues, ndigjues, shitës, shpenzues... But authors of the past used words borrowed from Greek, from Latin etc. We use Albanian vocabulary to express kinship relations: atë, bir, grua, mbese, motër, nënë, vëlla...; vocabulary items that marks the occurrence of nature, way of life, some animal names and work tools: bresher, dash, dele, diell, dite , dhi, nate, toke, re... Borrowings from other languages, especially from Latin, are taken when translating or adapting religious works, so they had to use a foreign term that lacked the Albanian at that time. A majority of these foreign words had entered in the Albanian language earlier. This is mainly noticed in Pjetër Bogdani works. He comes with a rich lexicon because he translated works that treated religions and not religious matters. So he had to use a broader terminology for the various scientific disciplines, such as literature, geography, geology, astronomy, etc., terms that Albanian at that time did not have. Terms: alegori, analogji, gramatikë, gjenezë, histori, kozmografi, matematikë, meteor, monarki, original, parabolë, poet. Thus, the authors enrich the vocabulary of old Albanian with international words that have already been acquired by Albanian and now are part of its vocabulary.

Although the Ottoman invaded our country for almost a century, there are not many Turkish words used by authors of XVI-XVII century. In "Meshar" of John Buzuku we find few words of a Turkish origin: cohë, dolloma, kallauz, tepsi; te vepra e Pjeter Budit: cohë, pazar, raki, shend, terezi...; The vocabulary used by Franc Bardhi and especially in the works of Pjetër Budi we find more words of a Turkish origin: bahçe, haci, hazar, hambar, harac, ibrik, kadi, kasap, kazan, konak, ode, oke, top, pasha, sanxhak... In all works of ancient authors we find particular Turkish terms related to administration, the feudal system, cuisine, urban planning, etc.. We also find words od Slavic origin used by the old authors: ças, udob ...; words of a Greek origin are rare (except international lexicon).

Another layer of vocabulary in the works of authors of XVI - XVII centuries constitutes new words created by them. They enriched the lexicon of Albanian words created by words within the Albanian language or by means of tracing, using several ways of forming new words. So, there are formed neutral nouns from abstract qualifying adjectives: të mirët, të padijtunit, shkruemit...; abstract qualifying nouns with the suffix - i or - ri: deshmijeni, dhuni, kerthinjeni, parabijeni...; abstract qualifying nouns with the suffix - ri: bashkari, perngjashmeri ...; composite nouns: dijekeqi. It is obvious that old authors created words by using words within Albanian language and under the laws of its development. But a good part of neologisms remained limited in their actions but that was only for a short time. Among those not in use, there are words correctly formed. Sometimes they can be reused for special stylistic purpose: dredhje "ciklon", hijëze "ombrellë", humboj "bie në fund", ndoroj "administroj", peshksuje "pishinë", përmjalt "ëmbëlsoj"; ngushëlloj"...

Some of the words in the vocabulary of the old authors are not in use today. Those words today have changed their meaning or they are used in a few regions: me u grishune "thirrem" (of old authors), me gjegjune "degjoj" (today in dibra and arbëresh of Italy), gjellë "jetë", gjëllinj "jetoj", kripë "flokë".

In the eighteenth century Albanian language was written not only in the North, but also in other areas of the country. A numerous bilingual dictionaries were published which pose a very large extent the Albanian language vocabulary. A special group of words in the lexicon of works of the eighteenth century authors constitute of new creations. Many neologisms were created by Anonimi i Elbasanit and Theodore Haxhifilipi. So they come as precursor to nineteenth-century writers, but many of their neologisms are not part of the Albanian language lexicon. Eighteenth - century authors tend to use less foreign words. Even by this trend they are precursor of Renaissance. But we must emphasize here Bejtexhinj group (Nezmi Frakulla Hasan Zyko Kamberi etc.) whose writings are full of orientalisms and they go beyond the content. This does not mean that the Albanian at that time was poor in vocabulary, but bejtexhinj, under the influence of education, culture and languages of the East, used orientalisms inappropriately. The traditions of the Albanian vocabulary clearance from foreign words and words enrichment was developed further in XIX - XX centuries by using derived Albanian words.

The writers of the nineteenth century, fed with love for their country, language and national culture, proud of Albanians, dedicated their life to the promotion of the mother tongue, besides the organization and development of the national movement for independence. Patriotics raised our national culture and traditions and worked diligently for extensive script. Renaissance wanted the spread of the script to achieve a dual purpose: to strengthen the Albanian national consciousness union and to show the world that Albanians are a nation of their own, with their own special language and rich, ancient culture. The writers of the nineteenth century brought to light many beautiful words that belonged to spoken language which showed an expressive range of our language ability. Constantine Kristoforidhi 
worked several years to collect undiscovered treasure of the Albanian language in different provinces and compiled a dictionary. Naim Frashëri, Jeronim de Rada, Andon Zako Cajupi etc. found in the language of the people, inexhaustible resources words and expressions as well as opportunities for new creations. They tried to get rid of words that were of a foreign source.

Cleaning of the Albanian language from foreign words need to replace them with words created from the language itself. On the other hand, the width of the works themselves by authors required a richer vocabulary with words that expressed various nuances of thought.

After independence was declared in 1912, in accordance with the new social, economic, political, cultural situations, Albanian underwent other developments, mainly in the lexicon. New started to be used in different fields of linguistic activity and certain social classes. Meanwhile, it was not done enough attempts to purify the language from foreign words as done during Renaissance period. In the '20s of the twentieth century in the Albanian language entered words of neolatine, French and Italian origin, mainly in the field of terminology. At that time many words entered from English as borrowings. For some intellectual people foreign words started to become fashion. In 30s many Italian words entered our language, especially in the field of technique, agriculture, industry, art, etc. Fascist invasion, when the Italian was also taught in our schools, the flow of words from this language grew more. But there were patriots such as $\mathrm{L}$. Gurakuqi, A. Xhuvani etc. that made efforts to clean our language.

The second half of the twentieth century down to nowadays represents a dynamic period of development, enriching the vocabulary of Albanian language during major economic, political, social and cultural life changes in our country that required a wealth of lexical semantic much greater than the previous periods, the words to express meanings with subtle nuances of thought to meet the requirements of production, education, culture, science, art, etc.. At this time was primarily insisted replacement of unnecessary foreign words with words created by the Albanian words itself. There were created new words to express new concepts, apart from adapting words from other languages, when this has been necessary. So the Albanian vocabulary is greatly expanded.

Meanwhile, in these last fifteen years, as a result of changes in the socio-political and new developments in the economy, the democratization of the life and the opening of the country's relations with the world, the Albanian vocabulary witnessed a rapid internal motions in some of its classes. To be noticed is the fact that Albanian words have been generalised by popular linguistic resources creating new words, but also the entry of many foreign words, some obviously warranted by areas of new concepts, and many others that are not necessary because that was somewhat overshadowed care to preserve the purity of our language of Albanian speech protection without denying a certain "snobbery" that linguistic appeared mainly in intellectual social classes, in areas of political-social activities, officialadminastrive, publicity etc...

Finally you can re-emphasize that vocabulary of today's Albanian language includes all words that serve us to communicate with one another. This lexicon includes very old words from the indoeuropian source or from other languages, words that are preserved over the centuries in the lives of our people and those that are created and entered into use as needed, words that have arisen during the development of social, economic, cultural and mental of Albanian people in different historical periods. "In today's Albanian language lexicon are accepted words that belong to both dialect. We use provincial dialect words, restricted words in certain area, in colloquial or written form".1

\subsection{Regional and dialectal lexicon}

Dialectal lexicon is limited. It is a glossary of the dialect or part of a special spoken language covering a limited territory. The two dialects of our language are to close to each other, firstly, because most words are the same for both dialects. They exchange words together. Also, borrowed words become the property of the dialects and brings the two of them them closer. All this part of the common vocabulary of lexical layer comprises two dialects of Albanian in general. Lexical, phraseological or semantic units of this layer are not dialectical or region words even when they are of a regional dialectal source. They belong to the common Albanian language. Thus, amtar, bishtuk, bjerr, bjeshkë etj... etc ... can not be called regional regardless of their initial origin.

Regional dialect words are those words that are used only in one or in a particular dialect.. So in the northern dialects: me bujte, tarnagop, turre etc. In the south we have: kaçke, gjiton etc.

Regional or dialectal words may be words or their meanings. We have dialectal words when in the other dialect it is not used at all because for the same concept there is another word: çikë "vajzë", gastare "qelqe" etc.

1 J. Thomas, Lexicology Albanian language, Toena Publishing House, Tirana 2006, p. 245-252 
Dialectal or regional words can also be seen from another side. We see if they have or not a common word in Albanian, eg. Kumbullore in the South / molla t'arta = in common domate. In these cases it is easier to assign the general standard rate. It is different with regional dialect words if there is not a common synonym, except one word in dialect or one in the other dialect. In this case if the common norm is taken one of them, the other remains limited in a dialect or in colloqual.

Words with phonetic differences that have a regional dialectal pronunciation are regional or dialectal phonetic variants: çube "kaçube" etc. Borrowings from other languages, when introduced only in one dialect such as gjiton (from Greek), gjiton (from Turkish) are recognized and used only in Northern dialects. In this case, we accept them as a dialectal or regional words.

Dialectal words are always distinguished by provincial rate against our standard lexicon of language because they reside outside the borders of unified language. However, as it has been said before, dialectal and regional lexical fund is an inexhaustible source for enriching the standard language vocabulary with words or meanings of words. So, they have become property of the standard language. These words are of dialectal origin: almise, i afte, anije, gogel etc.

\subsection{The regional or dialectal words are encountered in dialectal discourse, in speaking or oral folk literature}

They also are used in the artistic literature, when the topic requires it, to stereotype a character or a certain social environment. When we qualify words as dialectal or provincial we should make clear what we have in mind: which dialect the words belong to, their situation today outside the borders of standard language or their values in artistic literature use. These are varying degrees of provincial acquisition of vocabulary which constantly makes the language according to its needs.

Regional dialectal vocabulary of the Albanian language is traced, it is gathered and published in regional dialect dictionaries, explanatory dictionaries, journals etc.. "It is also studied to discover values and to pave the way toward wider use."

\subsection{Words that are accepted in standard Albanian dictionary}

Based on material from the works of authors such as Mjeda, Fishta, Migjeni, Koliqi we conclude that a total of approximately 690 words, more than half are accepted in standard Albanian dictionary. Those words have become property of the standard language which yield an additional of lexical, semantic and stylistic elements. So they are accepted in standard Albanian according to the following graph:

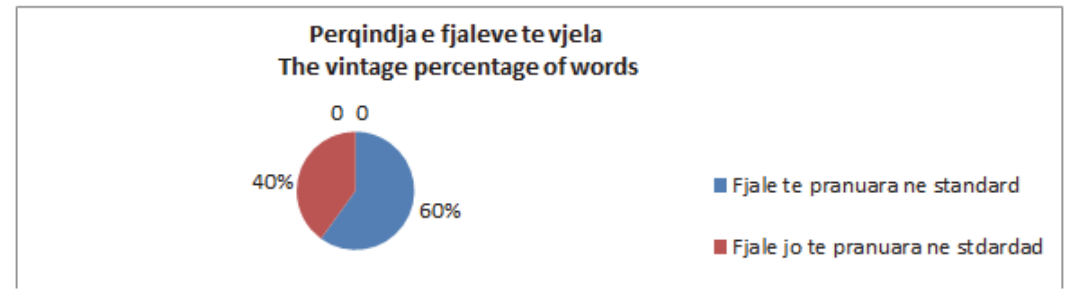

\section{Figure 1}

The following categories are accepted in standard grammar: nouns, adjectives, verbs, adverbs, pronouns, interjections etc. Their frequency can be presented as in the following graph:

2J. Thomas, Lexicology Albanian language, Toena Publishing House, Tirana 2006 f.272-279 


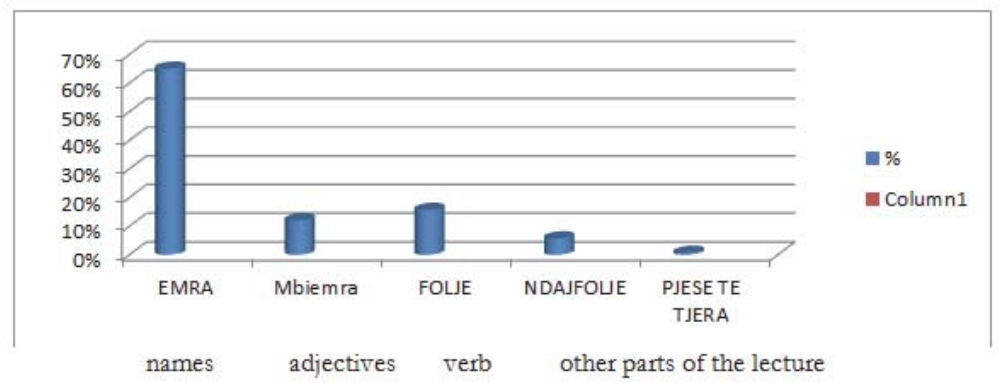

\section{Figure 2}

\subsection{Nouns}

The mostly accepted nouns which are related to:

a) Nouns with a concrete meaning, related to the nature of the workers lives, agriculture, livestock, etc. as jetesa, angari, caruqe,carani, duvak, doke, dollma, furkë, fërlik, fuzhnje, gastare, havani, ki, muranë, shek, shakull, telatin, turr, tërfurq, kopanë, kartuç, kular, zhgun, çini, çardak, fultere, gajtan, kotull, avullore, amëti, ahuri, bire, bishtuk, bëz, bohçe; pjese te trupit: kërçik, kollçikë, parzme, rrëcok, rradake, rrashtë, et;j dukuri te natyrës: boke,curril, curri, gërxheli, grazhd, glinë, hulli, krep, karpa,log, mriz, rrege, rrëmore, suvale, shteg, shullë, zabel, bjeshkë, grunore, ograjë, sukë; kafshe, bime:bolle, berr, gjok, kaçubet, kacadre, kaçirubë, kaçubë, kërcu, magjar, meçka, zekth, beg, çetinë, cung, grigjë, grethi, krënde, krizantemë etc. ...

b) abstract nouns: degame, erz, fitme, gajret, gjëmë, gjasë, kopalla, kamat, moh, ofshe, pasha, qokë, rrokullia, sahan, tube, amë, ahtët, apoteozë, akord, buzëmbrëmje, bend, burbuj, cok, duhi, duhmë, hair, kalesa, kompromis, kut, uzdaje etc.

c) Nouns related to history, war etc. as asqer, agzot, batare, birucë, bejleg, dushman, frëngji, harbi, kaush, mejdan, nizam, timar, zhavellë, vezme, gazep

d) Nouns of people, family members etc.: axhami, braci, katallan, kërthi, loke, probatin, buqari, camërdhok,emtë, ferishte, gabel, hyri, hajn, igumen, kasnec, shishman etc.

\subsection{Adjectives}

Adjectives mainly used:

a) those formed with the suffix - hem (these kind of adjectives maintain a direct connection with the lexical meaning of the corresponding verb. The feature that marks the adjectives may be related only to a particular sense of the verb which constitutes the topic such as $i$ kobshëm, $i$ lakmueshëm, i përloshem, $i$ turrshëm, $i$ thekshëm, etc.

b) those formed from the verb participles ( these adjectives have passive sense. They give the feature of the result of the action expressed by the verb which constitutes word- topic such as $i$ ligështuar, $i$ çartur, $i$ çmeritur, i dalldisur, i mekur, i molisur, i nëmur, i okupuar, i praruar, i soditur, i sosur, i shpulpuar,

c) those formed as a contextual composite in literature: dëmsjellës, epshkaperthyes, tragjikomike, zemerdhembshmi.

d) those borrowed from italian: melankolik, i okupuar, pompoze, delirant, i bruztë etc.

e) those which are largely qualitative ( these adjectives designate a quality attribute that can be directly grasped by using the senses. They can be thinkable and conceived ) such as biramel, çufrak, gratçore, gërgëlac, katallan, kërthi, i vobektë, i ligët, anak, bajate, bleroshe, camërdhok, epërm, i ngratë, i ndragtë, përdorake, rrotullore, i rremë, shpotar, teveqel, i vranët, zemerdhembshmi, zverdhake, pullali etc.

Lexical content studied rejects the wrong thought that discourse is characterized by people from specific vocabulary word denoting common items of everyday life. This lexcon is not poor. The truth is that the whole set of words collected includes large layers of abstract, spiritual word world and various relationships. These words denote features of actions, thoughts subtle nuances of different shade exciting, with a great semantic variety. 


\subsection{Verb}

a) verbs that designate actions performed and undergone by the subject itself such as: çapoj, davaris, gërvall, kukat, merita, ndrag, ngujoj, plandos, rys, skapulloj, zatet, zdryp, kalamend, korit, konstatoj, këndell, kastigoj, qyr, kallëzoj, kinse, ligështoj, avit, bëzaj, birrem, but, cungoj, çart, dikoj, dihat, dëlir ekzaltoj, urëtoj, fshaj, falem, faroj, galdoj, gjata, has, mësyj, nikel, ngas, ngurroj, ndryj, përpiloj, rreshk, ravigoj, rropos, rrok, rejë, sos, shpik, çel, grilloj, kij, kthjell, kapërthehem;

b) impersonal verbs or verbal expressions that designate atmospheric phenomena, natural or characteristic actions of animals and therefore are used only in the third person singular such as agullo (mëngjesi), farfurit (dega etj) gurron (përroi), mugullon (bari), pingëron (zogu, zana etj); impersonal verb veton etc.

c) verbs borrowed from Italian language: konstatoj, dëlir, ekzaltoj, galdoj, përpiloj;

\subsection{Adverb}

Adverbs are less in number compared to other parts of speech and they are classified as:

a) Determinant adverb that designate a feature of the action expressed by the verb and the degree of intensity of this action or feature: ligësisht, hovahov, palmuç, ani, fare, dyst, orok prore, paq;

b) circumstantial adverbs that designate circumstances in which the action is expressed by the verb such as (së) voni, kundruall, kurrkah, këtupari, kund, këtejpari, gjithkah, herherëra, ngjat, rreth e rreth, rrethas, atypari;

\section{Words that are Not Accepted in Standard Language}

Words, which are not accepted in standard language are less in number and belong to different parts of speech. In the graph below are shown the percentages of different parts of speech:

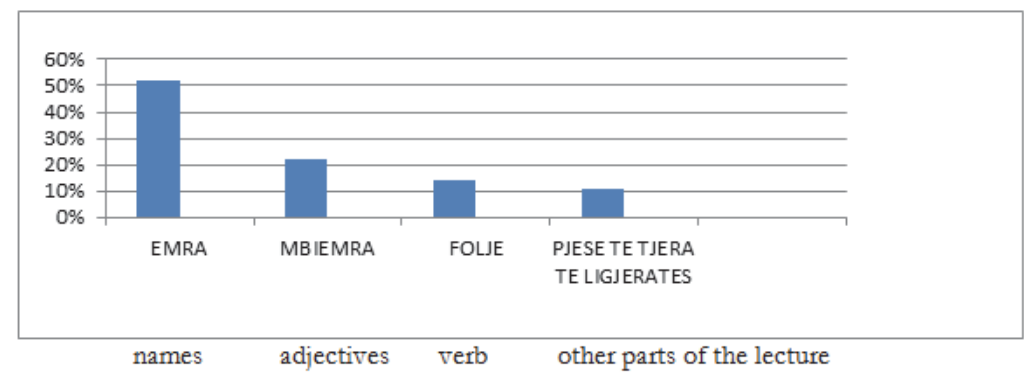

\section{Figure 3}

\subsection{Nouns}

A certain number of nouns which belong to different fields of life are not accepted. For example:

a) regional words: ahë, ahmarrës, arkapia, drandofile, dullij, dugaj, nadje, putiri etc.

b) Turkish borrowings: aferim, byber, çerpet, hali, qull, karm, mekame; This includes those words which are formed by using the suffix -xhi; dedermahxhi, ehengexhi, postaxhi. This suffix is now substituted by the suffix tar.

c) historical nouns: arenzi, pyrg, pajade, pedane, lëtinë, hyqymet

d) Italian borrowings: definacion, fantom, inkarnacion, lavabo

\subsection{Adjectives}

a) adjectives borrowed from Italian: ekstravagant, preçz, delikt, azurta (i e), lavruar (i, e) etc.

b) adjectives with the suffix -xhi such as: dedermahxhi, ehengexhi

c) unrecognized forms of adjectives: i burguem (the standard accepted form is i burgosur; the suffix -ue is often substituted by -uar, so in this case we would have I Burguar but in fact we have accepted the form derived 
from the verb burgo (s) and i burgosur); bumbulliore (onomatopoeia derivation); paras, unshëm (from the word uni- suffix -shëm feature of the northern dialect; it is formed the adjective unshëm while in standard form it is accepted $i$ uritur derived from the form uri); i paqtë (in standard form is accepted paqësor paqe + sor); i montuar, i marshëm, i njinjishëm (i njëtrajtshëm is the standard form accepted), e patrava etc.

2.3 Verb

a) verbs that express an action by the subject and the adjectives of the verb are the same word which falls such as: delikoj, dërmish, dath, dheshk, dhambçoj, idhnoj, inspiroj, jes, lecoj, leçit, mbshel;

b) impersonal verb: bërlyk, hullet, lartushtojn, përshqit etc.

c) verbs borrowed from the Italian language such as: impozoj, inspiroj, etc.

\subsection{Other parts of the discours}

a) adverbs: anames, fitefit, gjatëmot, kurrherë, kaiher, këndynaj, mje, mjes, mejës, ndara, nemose, njeti, pramur

b) pronouns: asish, gjthkënd, gjithkafja

c) particles: anima

d) interjections: deh, cok etc.

\subsection{Words that have been removed from dictionaries}

Dictionaries accept popular words and phrases from all dialects, even borrowings that are commonly used in spoken language and writing. If the linguists do not find the equivalent word, they accept the borrowed word. In some of the later dictionaries many of these words or racional words are removed from the dictionary and their number has been reduced. In order to compile a dictionary one should keep in mind to collect words from the spoken language by people living in a specific area because many words may have lost or changed meaning or may have been sunstitute by other words.

A number of words have been removed from some dictionaries but later they have been accepted again in others. We have come across these words that have been removed when comparing "The Albanian Language Dictionary" 2006, "Today's Dictionary of the Albanian Language" 2002 "Dictionary of the current Albanian Language " 1980:

\subsection{Albanian glossary}

Ahmarrës ${ }^{3}$ i m.sh. -it qe shpaguhet për një te keqe, për një dhune, për një krim, a për një padrejtësi, për një fyerje, për një qortim a kritike etj

Bajagi $^{4}$ ndaj bised 1. Ne sasi a ne menyre te mjaftueshme, aq sa duhet aq sa mjafton etj 2. Bised. Ne menyre te ndjeshmea te dukshme 3.perd. kallez Mjafton

$\mathrm{Baxhi}^{5}$,-a f. sh -(të) vjet bised perdorej per te thirur me nerim nje grua te moshuar

Bërlyk/et ${ }^{6}$ vetv $-(u)$ - ur.zhgerryhet per toke e pellet (per bagetine e trashe)

Delirant ${ }^{7},-$ e mb. Libr1. Edhe si em qe flet perçart 2. Fig entuziast, i dalldisur

Ekzalt/oj ${ }^{8}$ kal. -ova, -uar libr 1. Ngre, lartesoj dike ne grade 2. Lavderoj shume

Erët/oj ${ }^{9}$ kal. -ova, -uar mbush me ere, kundermoj

Fatkob ${ }^{10}$,-e mb. Edhe si em. fatzi

Flanikth ${ }^{11}$,-a m.sh -a,-at kafaz zogjsh; kotec pulash

Fluid $^{12}$,-e mb 1. Qe mund te rrjedhe 2. Libr. I pangulitr, I ndryshueshem

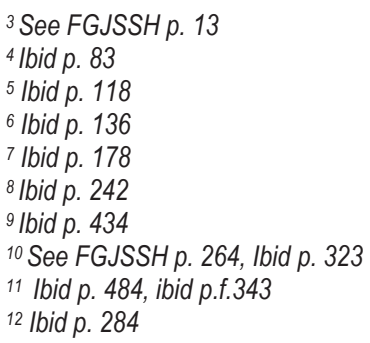


Goped/ër ${ }^{13}$, -ra f. sh -ra, -rat .ush. vjet top qe hidhte gjyle te rrumbullakta dhe mbushej nga gryka

Hiti/a f.sh ${ }^{14}$-(të) krahin 1 nxitim, ngut 2. zell

Idhnak ${ }^{15}$,-e, mb ose idhnar,-e 1.Qe zemerohet shpejt e mban inat, zemerak; i rrembyer e i ashper. 2. Fig qe vjen me vrull, i papermbajtshem 3. Fig qe ka te ftohte, te hidhur, i ashper, i eger

Igumen $^{16}$,-i m.sh, -ë(t) kryetari i murgjeve te nje manastiri ortodoks

Kacuk ${ }^{17}$ ndaj galiç

Kallçikë18,-t m. sh kallca

Kasnec ${ }^{19}$,-im. Sh ë(t) vje 1.lajmetar 2. ai qe hap a reklamon me buje nje ide ose nje pune te dikujt tjeter; tellall.

Kullm ${ }^{20}$ (i)-ë mb ne ngjyre te mjaltit, i perhime ne te verdhe.

Okupuar $^{21}(i, e)$ mb i pushtuar.

Patalo/k22-ku m.sh. -qe, -qet krahin. vend i rrafshet, shesh i madh ku zakonisht beheshin dyluftimet.

Probatin ${ }^{23}$, -i m. sh -ë, -ët etnogr. vëllamë.

Prozh/ëm ${ }^{24}$, -i m.sh -e, -et pyl i vogel, korije, zabel.

Rub/ë25, -a f. sh.-a, -at krahin shami, shami e madhe koke.

Shimshir ${ }^{26}$,-i m.sh. -ë, -ët bot shkurre perhere e blerte me dru te verdhe.

Skapall/on ${ }^{27}$ jokal.v. III,- oi, -uar kercet fort e thekshem (kur diçka thyhet menjehere).

Stamastik ${ }^{28}$,-u m.sh -ë(t) qe ka dale nga kryqezimi i dy llojeve a i dy racave te aferta hibride, femije stramastik femije qe ka lindur nga bashkimi i dy racave te ndryshme

Vërgjiltë29 (t) mb i shkathet; djale i vergjilte

Vet/on ${ }^{30}$ pavet. -oi, -uar krahin vetetin

Yrysh $^{31}$ ndaj hov, vrull

\subsection{English glossary}

ahmarrës - the MH That 's a bad pay off for violence, a felony , or an injustice, for an insult , for a reprimand or critical etc.

1 bajagi to talks . A quantity sufficiently, enough just enough etc. 2 . Re . In order to ndjeshmea 3.perd visible . Suffice ears

Baxhi , -a f . sh - ( of ) years of talks duly utilized to Nerima an elderly woman

Bërlyk / s vetv - ( $u$ ) - ur.zhgerryhet for land and Pella ( for herds )

Delirant , the mb - . Libr1. Even as you mad em 2 . Fig enthusiastic , foolhardy

Ekzalt / OJ horse . - Ova, - ed Books 1 . Elevate, exalt someone in grade 2. Extol more

Rappers / OJ horse . - Ova, cleanly filled with wind, kundermoj

Fatkob , the mb - . Even as em . unlucky

Flanikth , m.sh -a -a -at the aviary, climbing frame

Fluid, the mb - 1. You can stream 2. EBook. The pangulitr, variable

\footnotetext{
${ }^{13}$ Ibid p. 565, ibid p. f 398

14 Ibid p. 398, ibid p. 687

15 Ibid p.710

${ }_{16}$ Ibid p. 399, ibid, p. 710

17 Ibid p. 755

18 Ibid p.851, ibid p.505

19 lbid p. 444, ibid p. 795

20 Ibid p. 910, ibid p. 505

21 Ibid p. f.718

22 Ibid p. 1385, ibid p. 943

${ }_{23}$ Ibid p.1551, ibid p. f. 846

24 Ibid p. 1561

25 Ibid p.1673

${ }^{26}$ Ibid p.1843, ibid p. 1012

${ }^{27}$ Ibid p.968

${ }^{28}$ Ibid p. 1795 , ibid p. 1210

${ }^{29}$ /bid p.1182, ibid p. 2158

30 See FGJSSH. p. 2149, ibid p. 1178

31 Ibid p. 2205, ibid p. 1490
} 
Goped / ER - ra p. sh - ra , - rat . military . years to throw ball cannon round and filled the gorge

Hiti / a f.sh - ( to ) every Province 1 hurry, hurry 2 . diligence

Grumpy , - e, mb or idhnar , the 1.Qe - fast upset of hate, petulant, abducted and severe . 2 . Figure that comes with momentum, irresistible 3 . Fig having cold, bitter, hostile, cruel

Abbot , the m.sh - , - s ( t ) is the head of an Orthodox monastery monks

Kacuk to squat

Kallçikë, t m . sh kallca

Harbinger , im . S h ( t ) 1.lajmetar 2 years old. He who opens a spectacular advertises an idea or a someone else's work ; crier .

Kullm (i) UK - colored honey, taupe in yellow .

Occupied ( $i, e)$ mb thrilled.

Patalo / $\mathrm{k}$, where $\mathrm{MH}$ - That, portrays every Province. Instead of flat, large square where usually took challenges.

Probatin , -i m . sh - $s,-s$ etnogr best man .

Prozh / er , - of - the m.sh, PYL small sites, grove, grove .

Rub / s, a f - . eg - a, -at every Province handkerchiefs, scarves big headache .

Shimshir , -i MH - S, - s bot permanently green shrub with yellow wood .

Skapall / on jokal.v . III - oi , - ed strongly penetrating cartilage ( when something breaks immediately ).

Stamastik, m.sh - s - u ( t ) that has emerged from the crossbreeding of two types that two close races hybrid, children stramastik child who was born from the merger of two different breeds

Vërgjiltë ( $\mathrm{t}$ ) $\mathrm{mb}$ agile ; boy vergjilte

His / Pave on . - $\mathrm{O}$, - ed every Province sparkle

Yrysh to burst, momentum

Google Traduttore per il Business:Translator Toolkit

\section{Results}

In the end we have come to these conclusions:

Literary language not only gets the dialects and idioms, but also affects them, expands the vocabulary, processes the words and develops them further into meanings, new formations, and in their expressive values.

We have always been based "on Albanian Language Dictionary" 2006.There are accepted more than half of words collected from authors like Mjeda, Fishta,Koliqi and Migjeni. This shows that regional and dialectal lexicon has played an inportant role in the vocabulary enrichment .

We confirmed that a large number of nouns, adjective (qualitative), adverbs, particles, interjections, pronouns are accepted. These words belong to various parts of discourse. These words are thought to be purely Albanian words from an early period. For example: drom - rrugë , which is thought to have come from Greek .

Words not accepted are mostly full regional words. They are used in Shkodra and beyond this regjional dialect. The authors have been responsible to submit northern dialect including all its forms. They collide in literary rate due to rotation. In some cases they are borrowed from Slavic, Italian or Turkish language etc. Such words are limited as dialectal and as borrowings but they can also be considered as old words as we have mentioned above. Studying the lexicon we also came across unknown antotonyms. They have not been created by ther authors. For examples: ngatërrimtar - zhgtërrimtar. This means that dialectal words may serve for the formation of new words as well.

In the end we compiled a dictionary intending to explain regional and dialectal words, their meanings most of readers do not know. This minidictionary may serve to explain meanings , lexical field, links to other words etc.

\section{References}

Çabej , Eqrem . Introduction to the history of the Albanian language . Tirana, Çabej , 2008.

Bulls, Benedict . Dictionary word. Tirana, Toena, 2005.

Elsie, Robert . History of Literature. Tirana, 1997.

Fisher, George . Lahuta of Malcis . EUGEN, Tirana, 2003

Haxhillazi, Paul . " Observations on verbal adjectives with the suffix ment . " Philosophical Studies, 1969, pp. 145.

IGJL , ASHSH . Albanian Grammar I. Tirana, Maluka , 2002.

Congress Albanian language spelling I. Tirana: Mihal Duri , 1972.

Studies on vocabulary and the formation of words in Albanian II . Tirana , 1972. 
IGJL , Language Albanian alphabet and the Congress of Monastir . Tirana, Mihal Duri , 1972 .

ISGJ . Albanian language dictionary . Tirana : Toena, 2006.

Albanian dictionary today . Tirana : Toena, 2002.

Glossary of today's Albanian language. Tirana, 1980.

Kapinovo, Clyde. A series that rediscovers Ndre Mjeden aesthetic . August 11, 2010

Koliqi , Ernest . Commercial flags . Covenant, 2009, U.S. " Naimi " , Tirana , 2008

Memushaj, Rami . Introduction to Linguistics . Tirana : Toena, 2008.

Migjeni . Works . Tirana, 2009, Illustration

Mjeda, Ndre . Juvenilja .

Quku, Mentor . Congress will fail without Mjeden Monastery .

Thomas, Jani . Lexicology Albanian language. Tirana : Toena, 2006.

Xhevad Lloshi Emil Lafe. Albanian state and the development of literary Albanian language 